\title{
DIVIDA EXTERNA E CRESCIMENTO ECONOMICO: UMA ESTRATÉGIA DE LONGO PRAZO PARA O CASO BRASILEIRO
}

Reynaldo de Souza Motta*

RESUMO

o presente artigo tem por objetivo utilizar modelos de otimiza ção do crescimento econômico e da evolução da dívida externa na si mulação da economia brasileira, com vistas a proporcionar melhor controle e atingir a estabilização e posterior redução do endivida mento. procura-se estudar a relação entre os custos e os beneficios do afluxo de recursos externos, buscando-se uma avaliação sis temática de alternativas de crescimento econômico e endividamento. Tendo comı finalidade o provimento de uma base para um planejamento econômico para o Brasil - considerado um período de 20 anos -, os modelos lesenvolvidos utilizam-se da programação linear como me todologia, levando-se em conta a maximização do consumo durante o período dio plano e pós-plano (benefícios) e a minimização das despesas extnernas de juros ao longo do plano (custos). Além das equaçōes de drefinição e das restriçōes estruturais e comportamentais normais em modelos de programação econōmica -, a fim de prevenir os cilaçōes socialmente indesejāveis ou . nstitucionalmente inviāveis, estabelecrem-se restriçōes políticas, tais como um limite inferior para o crescimento do consumo "per capita" e um teto relativo para a evoluçãio da divida externa.

* Departamento Econömico do Banco Central do Brasil. 


\section{ABSTRACT}

The present essay aim at using economic growth optimization and foreign debt development nodels to simulate the Brazilian economic system so as to attain its better management and greater stabilization, eventually leading to an ulterior debt reduction. The cost-benefit ratio of the foreign resources inflow was appraised so that a systematic approach to the economic growth and indebtedness alternatives could be implemented. The models advanced, whose main goal is to lay the foundations of a Brazilian economic scheming (given a 20 year period), borrow their methodology from the linear programming rudiments, taking into account that a) consumption levels will be in their highest during the project and afterwards (benefits) and b) the foreign dẹt-service charges will be at their minimum level (costs) as long as the project is under way. Besides the definition equations and the structural and behavioural constraints - often used in economic programming models - certain political limitations were included (such as a lower limit for the growth of per capita consumption and a relative ceiling for the foreign debt development) in order to prevent either undesirable social unsteadiness or unattainable institutional expectations from happenning. 


\section{INTRODUGAO}

o objetivo deste artigo e utilizar modelos de otimizaçāo do crescimento econômico e da evolução da dívida externa na simulação da economia brasileira. o que se almeja é a obtenção de taxas razoáveis de crescimento econômico, buscando-se simultaneamente um melhor amento da posição do Brasil com respeito ao comércio exte rior, tanto pelo aumento das exportaçōes como pela substituição de importaçōes, com vistas a proporcionar melhor controle e atingir a estabilização e posterior redução da dívida externa.

Ao buscar-se viabilizar a estratégia de redução da dívida externa dentro de certo prazo, procura-se verificar as consequências dessa estratégia sobre os fatores mais relevantes da economia em expansão. Nesse sentido, um dos principais aspectos que serão leva dos em conta é a relação entre os custos e os benefícios do afluxo de recursos externos para a promoção do crescimento. o estudo dessa relação será baseado em uma avaliação sistemática de alternativas de crescimento e de endividamento, ao contrário do que, de modo geral, tem sido verificado em muitos estudos de planejamento, onde o afluxo de recursos externos é considerado sobre uma base his tōrica ou é tomado como fixo, como dado, ou ainda é ignorado.

A finalidade desta pesquisa é prover uma base para um planeją mento económico para o Brasil. o modelo desenvolvido neste trabalho consiadera um período de 20 anos e utiliza-se da programação li near como metodologia, levando-se em conta a maximização do consumo durante o período do plano e pós-plano (benefícios) e a minimização das despesas de juros ao longo do plano (custos). Como limi tantes do objetivo geral, além das equaçōes de definição e das res triçōes estruturais e comportamentais, estabelecem-se restriçōes políticas, como, por exemplo, que o consumo "per capita" tenha um 
certo crescimento mínimo durante o periodo do plano e que a divida externa seja mantida dentro de determinados limites relativos.

Neste trabalho, tem-se como balizamento a exploração de estra tégias de crescimento ótimo, nas quais o afluxo de recursos externos e a dívida exteina possam ser variados dentro de determinados limites. Em particular, procura-se estudar as influencias sobre o crescimento do produto exercidas por dois tipos distintos de politica de endividamento externo, analisando-se as vantagens e desvan tagens de cada um: uri em que o ritmo de endividamento permaneça em seu processo contínuo de crescimento e cutro em que se coloca um marco a partir do qual possa haver redução da divida externa. Procura-se analisar a evolução de objetivos conflitantes, tais como rá pido crescimento do produto e declínio da divida externa, a fim de que se possa escolher sistematicamente a estratégia mais proveitosa para a sociedade brasileira, observadas as prováveis futuras condiçōes da economia mundial.

o modelo desenvolvido neste trabalho tem, como elementos críticos da estratégia do desenvolvimento, os empréstimos e a divida externa. Baseando o crescimento mais na capacidade de investir do que na de poupar, eles mostrani como utilizar-se do endividamento externo como meio para sua prōpria eliminação.

2. 0 MODELO

o modelo utilizado tem como metodologia básica a programação linear.

o objetivo é otimizar uma funçāo de bem-estar social, na qual se procura a maximização de benefícios - traduzidos no consumo tan to durante os anos do plano como em todos os posteriores - com os menores custos possiveis - representados pela despesa de juros sobre a divida externa durante os anos do plano -, ambos tomados dinamicamente (a cada periodo).

Além das relaçōes de definição, de estrutura e de comportamen to, utilizam-se também, como restriçōes, diversas metas políticas, dentre as quais se destacam sobremaneira as restriçōes relaciona das com a divida externa, tendo em vista ser o confronto entre a evolução desta última e a do produto o principal escopo deste tra- 
balho. Da mesma forma que a função-objetivo, as restriçōes têm o carāter d unāmico, eis que são apostas para cada periodo, que é de um ano.

As variāveis contidas no modelo sāo relacionadas a seguir, juntament: com seus respectivos significados:

a) A - amortização total dos empréstimos tomados;

b) $A^{P}$ - amortização programada dos empréstimos tomados até o a no-base:

c) C - consumo;

d) D - divida externa bruta;

e) E - empréstimos tomados;

f) I - investimento

g) $I^{2}$ - investimento no setor convencional;

h) $I^{A}$ - investimento estrangeiro direto liquido;

i) $I^{\Gamma l}$ - investimento no setor de melhoramento da balança comercial;

j) J - despesa liquida de juros;

k) M - importaçōes convencionais (exceto despesa de juros);

1) P - produto nacional bruto;

m) $\mathrm{P}^{\mathbb{2}}$ - produção convencional;

n) $\mathrm{P}^{\mathrm{m}}$ - produção para melhoramento da balança comercial;

o) $\mathrm{R}$ - reservas internacionais;

p) S - poupança doméstica bruta;

q) $\mathrm{x}$ - exportaçōes convencionais (exceto receita de juros).

o modelo contempla dois setores: um convencional e outro para melhoramento da balança comercial. o primeiro refere-se ao tipo de investimentos e de produção existente até o ano-base e seria o úni co a existir também nos anos abrangidos pelo plano, caso este não horvesse sido elaborado. Como setor de melhoramento da balança coin cial, consideram-se os investimentos e a produção destinados a 
substituir importaçōes e a expandir exportaçōes. A hipōtese de que deva haver maior ênfase nos produtos que requeiram uma relação incremental capital/produto para o setor de melhoramento da balança comercial superior à relação do setor convencional constitui-se em uma diferença importante entre os dois setores. Dessa forma, um es treitamento do hiato de comércio via setor de melhoramento da balança comercial tem como custo uma redução na taxa de crescimento do produto.

As importaçōes e as exportaçōes sāo ditas convencionais, em virtude de haver, durante o plano, uma parcela do produto - a produção para melhoramento da balança comercial - que altera os valores efetivos dos componentes da balança comercial. Além disso, dos valores das importaçōes e das exportaçōes convencionais são abatidas respectivamente as despesas e as receitas de juros, que, balanceadas, se constituem em outra variável do modelo, qual seja, a despesa liquida de juros. Portanto, as variáveis $\mathrm{M}$ e $\mathrm{X}$ do modelo nāo registram as importaçōes e as exportaçōes conforme se apresentam na contabilidade nacional. A variável $M$ representa as importaçōes menos as despesas de juros, enquanto $\mathrm{X}$ significa as exportaçōes menos as receitas de juros. Por outro lado, há que se considerar que a produção para melhoramento da balança comercial ( $\mathrm{P}^{\mathrm{m}}$ ) contém, durante os anos do plano, uma parcela que reduz o valor efetivo das importaçōes e outra que aumenta o das exportaçōes. Dessa forma, o valor das importaçōes em um dado ano, dentre os contem plados pelo plano, deve ser computado subtraindo-se de M a parcela de $\mathrm{P}^{\mathrm{m}}$ correspondente à substituição de importaçōes e somando-se ao resultado a despesa de juros; semelhantemente, o valor das exportaçōes deve ser computado somando-se a $\mathrm{x}$ a parcela de $\mathrm{P}^{\mathrm{m}}$ corres pondente à expansāo das exportaçōes e a receita de juros. A variāvel $J$ (despesa líquida de juros) nada mais é do que o resultado da diferença entre a despesa e a receita de juros.

Listam-se, a seguir, os parämetros:

a) $\alpha$ - taxa marginal de poupança;

b) - taxa máxima possivel de crescimento do investimento;

c) $\eta$ - ponderação da renda do ano terminal do plano;

d) $\rho$ - taxa de crescimer.to do produto pós-plano; 
e) a - prazo médio de amortização dos novos empréstimos (em anos);

f) c - relação dívida externa líquida/exportaçōes convencionais mais parcela da produção para melhoramento da balança comercial destinada a expandir exportaçōes;

g) d - taxa exōgena de crescimento do investimento estrangeiro direto líquido;

h) e - fração da produção para melhoramento da baìança comer cial destinada a substituir importaçōes;

i) $\mathrm{f}$ - relação reservas internacionais/importaçōes convencio nais mais despesa líquida de juros e menos parcela da produção para melhoramento da balança comercial desti nada a substituir importaçōes;

j) i - taxa de desconto durante os anos do plano;

k) $j^{i}$ - taxa internacional de juros;

1) $j^{S}$ - taxa de risco ("spread") ;

m) $k^{\text {Na }}$ - relação incremental capital/produto para a produção convencional;

n) $k^{\pi n}$ - relação incremental capital/produto para a produção para melhoramento da balança comercial;

o) m - prazo médio de carēncia esperado dos novos empréstimos (em anos);

p) $m^{\cdots}$ - taxa marginal de importação com relação ao consumo;

q) $\mathrm{m}^{\dot{\lambda}}$ - taxa marginal de importação com relação ao investimen to;

r) n - número de anos anteriores ao ano terminal do plano, a partir do qual não mais se tomam empréstimos externos;

s) p - taxa esperada de crescimento da população;

t) q - taxa mínima de crescimento do consumo "per capita";

u) $r$ - taxa de desconto sobre o consumo pós-plano;

v) x - taxa exōgena de crescimento das exportaçōes convencionais;

w) $\mathrm{T}$ - ano terminal do plano. 
A partir da definição dos parâmetros $\mathrm{T}$ e $\mathrm{n}$, no ano $\mathrm{T}-\mathrm{n}$ não mais serão tomados empréstimos. o marco de transição do segundo pa ra o terceiro estágio da dívida externa' verificar-se-à quando os empréstimos se igualarem às amortizaçōes, o que deverá ocorrer antes do ano $\mathrm{T}-\mathrm{n}$.

objetiva-se maximizar a seguinte função geral de bem-estar:

$$
B=\sum_{t=1}^{T} \frac{c_{t}}{(1+i) t}+n P_{T}-\sum_{t=1}^{T} \frac{J_{t}}{(1+i) t},
$$

onde

$$
\eta=\left(1-\alpha_{T}\right) \sum_{t=1}^{\infty} \frac{(1+\rho)^{t}}{(1+r)^{1}+t} \text {, para } \rho<r .
$$

Na funçāo-objetivo acima exposta, observam-se trēs partes dís tintas:

a) soma do consumo (descontado) de todos os anos abrangidos pelo plano;

b) indicador da soma do consumo (descontado a uma taxa diferente da do consumo durante o planol de todos os anos posteriores ao plano;

c) soma da despesa líquida de juros (descontada) de todos os anos abrangidos pelo plano.

o motivo de se descontarem o consumo e a despesa líquida de juros reside na preferēncia intertemporal: um beneficio no presente normalmente tem precedēncia sobre o mesmo beneficio no futuro, assim como qualquer custo no presente tende a exercer maior pressão do que no futuro.

(1) O segundo estágio começa quando a poupança doméstica é suficiente para financiar o investimento requerido, mas hä necessidade de se tomar emprestado para fazer face ao serviço da dívida. O terceiro estágio começa quando a poupança doméstica dá para cobrir não só o investimento requerido e os juros sobrc a divida, mas também a amortizaçào efetiva da dívida. Para uma compreensão pormenorizada do assunto, consulte-se Motta (1982, págs. 42a50). 
A mesma justificativa é dada para a diferença entre as duas taxas de desconto. Pressupōe-se que a sociedade tenha maior preferēncia pelo melhoramento do padrāo de vida durante o período do pla no, comparativamente com o de um futuro distante. Esse desejo pode ser satisfeito, atribuindo-se um valor para a taxa de desconto pós-plano (r) maior do que para a taxa de desconto durante o plano(i).

Em seus comentários sobre o artigo de Chenery-MacEvan (1966, pãg. 180), Milikan, referindo-se à taxa marginal de poupança, permitiu pensar-se que o modelo ganharia maior realidade se a citada taxa tivesse um crescimento ao longo do tempo. Tal pensamento deve-se à afirmativa de Milikan de que uma taxa marginal de poupança variável ascendentemente expressaria a intençāo de oferecimento de ajuda, por parte dos doadores, como um incentivo para persuadir o país receptor a elevar sua taxa marginal de poupança. Embora nāo seja esta a realidade da economia brasileira - à qual é destinado o presente modelo -, poder-se-ia pensar em outras justificativas para a aposição de uma taxa marginal de poupança crescente. Poder-se-ia arjumentar, por exemplo, que existe uma correlação positiva entre a referida taxa e a renda, de modo que, quando esta cresce, aquela tende a elevar-se; poder-se-ia também considerar a taxa em questão como um parãmetro político, no sentido de que, com o objetivo de promover-se uma auto-sustentação do crescimento da economia ao final do plano, seriam implementadas, durante o plano, medi das que a tornassem crescente ao longo do tempo. De qualquer modo, a fim de jar ao modelo um caráter mais genérico, possibilitou-se, ao parāmetro em questão variar ao longo do tempo, de maneira que ele pudesse ser tomado desde como fixo até como mutável anualmente, e assim pudesse satisfazer uma ampla ,ama de argumentaçōes. Por es ta razāo a considerando-se que a taxa marginal de poupança dos a nos pós-plano venha a ser igual à do último ano do plano, para se obter a taxa marginal de consumo (que se aplica à renda do ano ter minal do planol, basta subtrair-se a taxa marginal de poupança do ano terminal do plano da unidade $\left(1-\boldsymbol{\alpha}_{\mathrm{T}}\right)$.

Desdə que a taxa de crescimento do produto pös-plano ( $\rho$ ) seja menor do que a taxa de desconto sobre o consumo pós-plano ( $r$ ), a ponderação da renda do ano terminal do plano (n) terá um valor finito. Isto ocorre porque a expressão $\sum_{t=1}^{\infty} \frac{(1+p) t}{(1+r)^{T+t}}$ pode ser subs 
tituída por $\frac{1}{(1+r)^{T}} \cdot \sum_{t=1}^{\infty}\left(\frac{1+r}{1+r}\right)^{t}$, a qual é constituida por dois fatores finitos, sendo que o ültimo fator $-\sum_{t=1}^{\infty}\left(\frac{1+r}{1+r}\right)^{t}-$ não é mais do que a soma de uma progressão geométrica decrescente (razão igual a $\left.\frac{1+\rho}{1+r}<1\right)$, cujo valor converge para um limite finito.

o produto nacional bruto é composto pelos produtos dos dois setores, o da produção convencional e o da produção para melhoramento da balança comercial:

$$
p_{t}=p_{t}^{c}+p_{t}^{m} \text {. }
$$

Da mesma forma, o investimento total é igual à soma dos inves timentos nos dois setores:

$$
I_{t}=I_{t}^{c}+I_{t}^{m} \text {. }
$$

$O$ investimento total tem como fonte as poupanças doméstica e externa, e esta consiste no excesso de importaçōes sobre exportaçōes:

$$
I_{t}=s_{t}+M_{t}-x_{t}+J_{t}-p_{t}^{m} .
$$

Na equação (2.4), a poupança externa engloba, tendo em vista as definiçōes de importaçōes e exportaçōes convencionais utilizadas no modelo, a despesa líquida de juros e, por constituir-se em um fator de redução das importaçōes e de expansāo das exportaçōes, a produção para melhoramento da balança comercial. Esta última, con forme mostrado em Tinbergen (1970, pág. 227), funciona como uma "va riável de ajustamento", ou seja, aquela que tem a funçāo de estrei tar o hiato de comércio.

Além da poupança externa destinada aos investimentos, são ne cessários recursos para as amortizaçōes de empréstimos anteriores e para os aumentos das reservas internacionais. A totalidade dos recursus externos é proveniente de empréstimos e de investimentos estrangeiros diretos:

$$
E_{t}=M_{t}-x_{t}+J_{t}-P_{t}^{m}+A_{t}+\left(R_{t}-R_{t-1}\right)-I_{t}^{d} .
$$

A dívida externa sruta cresce em função dos empréstimos obtidos e é aliviada pela amo tizaçāo total dos empréstimos tomados: 


$$
D_{t}=D_{0}+\sum_{\tau=1}^{t}\left(E_{\tau}-A_{\tau}\right)
$$

A definição de hiato de comércio utilizada na equação conduz à sequinte formação da identifidade da renda nacional:

$$
P_{t}=C_{t}+I_{t}+X_{t}-M_{t}-J_{t}+P_{t}^{m} \text {. }
$$

Admitiu-se, no presente modelo, que as exportaçōes tradicionais, cujo produto é gerado através da relaçāo capital/produto da produção convencional, crescem a uma taxa determinada exogenamente:

$$
x_{t}=x_{0}(1+x)^{t} \text {. }
$$

0 investimento estrangeiro direto líquido, da mesma forma aventada para a exportaçāo, foi considerado exōgeno e com crescimen to exponencial ao longo do tempo:

$$
I_{t}^{d}=I_{0}^{d}(1+d)^{t} \text {. }
$$

Da amortização total dos empréstimos tomados constam duas par celas: a amortização programada dos empréstimos tomados até o ano-ba se inclusive e a amortização dos empréstimos tomados durante o período do plano. A primeira parcela trata-se, como já foi comentado, de um dardo, enquanto a segunda depende dos empréstimos tomados durante os anos do plano, do prazo médio de amortização dos novos em préstimos (a) e do prazo médio de carēncia dos novos empréstimos (m) . A amortização total dos empréstimos tomados é obtida pela seguinte expressão: ${ }^{2}$

$$
A_{t}=A_{t}^{p}+\frac{1}{a-m+1}\left(\sum_{\tau=1}^{t-m+1} E_{\tau}-\sum_{\tau=1}^{t-a} E_{\tau}\right),
$$

(2) Para um melhor entendimento da expressão (2.10), vejam-se, por exemplo, os valores das amortizaçöes totais dos empréstimos tomados referentes aos anos $2,4,3$ e 12. Supondo-se que $a=8$ e $m=3$, tem-se:
a) $\mathrm{A}_{2}=\mathrm{A}_{2}^{\mathrm{P}}$;
b) $A_{4}=A_{4}^{p}+\frac{1}{6}\left(E_{1}+E_{2}\right)$;
c) $A_{8}=A_{8}^{P}+\frac{1}{6}\left(E_{1}+E_{2}+E_{3}+E_{4}+E_{5}+E_{6}\right)$;
d) $A_{12}=A_{12}^{P}+\frac{1}{6}\left(E_{5}+E_{6}+E_{7}+E_{8}+E_{9}+E_{10}\right)$. 
para $t-m+1>0$,

$t-a>0 \quad e$

onde $A_{t}^{p}$ é dada.

A despesa líquida de juros de um determinado período é função da dívida externa bruta e do nivel de reservas internacionais ambos considerados no período anterior. A despesa bruta de juros é calculada, aplicando-se a taxa internacional de juros $\left(j_{t}^{\dot{j}}\right)$ e o "spread" $\left(j_{t}^{S}\right)$ relativos ao ano em curso $(t)$ à divida externa bruta do ano anterior $\left(D_{t-1}\right)$. Porém, ao admitir-se que as reservas internacionais são inteiramente aplicadas à taxa internacional de juros (naturalmente sem o "spread"), há uma receita de juros resultante da aplicação da taxa de juros do ano $t$ às reservas internacionais do ano anterior. Assim, a seguinte expressão é utilizada para ocál culo da despesa líquida de juros:

$$
J_{t}=\left(j_{t}^{i}+j_{t}^{s}\right) D_{t-1}-j_{t}^{i} R_{t-1} \text {. }
$$

Um dos pressupostos básicos do presente modelo é o de haver mão-de-obra ociosa na economia. Em decorrência, o crescimento da produção é função apenas do capital empregado. Então, a produção convencional de um determinado ano é limitada pela produção adicio nal à do ano-base conseguida com os investimentos no setor convencional, observada a relação capitial/produto do setor. Como de costume, admite-se que o investimento de um determinado ano gere uma produção adicional no ano seguinte:

$$
\mathrm{P}_{\mathrm{t}}^{\mathrm{c}} \leqq \mathrm{P}_{0}+\frac{1}{\mathrm{k}^{\mathrm{C}}} \sum_{\tau=0}^{\mathrm{t}-1} \quad \mathrm{I}_{\tau}^{\mathrm{c}} \text {. }
$$

Pressupōe-se que a produção para melhoramento da balança comercial requeira uma relação capital/produto mais alta do que a do setor convencional, e, por definição, o investimento no setor de me lhoramento da balança comercial só pode existir ao iniciar-se o plä no:

$$
\mathrm{P}_{\mathrm{t}}^{\mathrm{m}} \leqq \frac{1}{\mathrm{k}^{\mathrm{m}}} \sum_{\tau=1}^{t-1} \mathrm{I}_{\tau}^{\mathrm{m}} .
$$

Admite-se que a poupança esteja relacionada com a renda e que - parâmetro que relaciona estas variáveis seja a taxa marginal de poupança. Portanto, a poupança de um determinado ano pode atingir, 
no máximo, um valor correspondente à soma da poupança do ano anterior com o resultado do produto da taxa marginal de poupança do ano em curso pelo incremento da renda do ano:

$$
s_{t} \equiv s_{t-1}+\alpha_{t}\left(P_{t}-p_{t-1}\right)
$$

A função de importaçāo keynesiana tem para variāvel independen te a renda. Em Chenery-MacEwan (1966), bem como em Tinbergen (1970), a demanda por importaçōes é uma função da renda e do investimento. No presente modelo - do mesmo modo que em Shibly - Thirlwall (1981) - foi utilizada uma abordagem das necessidades de importa ção que consiste em desagregá-las em bens de consumo e bens de in vestimento:

$$
M_{t}=M_{0}+m^{c}\left(C_{t}-C_{0}\right)+m^{i}\left(I_{t}-I_{0}\right)
$$

Embora as taxas marginais de importaçāo possam ser tratadas como instrumentos de política econômica, aqui elas são tomadas como parâmetros técnicos.

Tem sido observada certa limitação na capacidade de um país subdesenwolvido em absorver aumentos na oferta de capital (veja-se Chenery-iracEwan (1966). Esse limite é incorporado ao modelo, através da aposição de um teto sobre o crescimento do volume investido em determinado ano, com relaçāo ao do ano anterior:

$$
I_{t} \stackrel{c}{=}(1+\beta) I_{t-1} \text {. }
$$

Razōes técnicas conduzem ao estabelecimento de uma restrição que previna decréscimos irrealísticos no nível de investimento. Também seria irreal que, mesmo näo havendo decréscimo no nível de investimento total, o investimento em um dos setores decrescesse a fim de compensar um grande incremento no investimento no outro setor. Por isso, o modelo inclui as seguintes restriçōes:

$$
\begin{aligned}
& I_{t}^{c} \equiv I_{t-1}^{c} ; \quad e \\
& I_{t}^{m} \equiv I_{t-1}^{m} .
\end{aligned}
$$

Através da maximização de benefícios (consumo) e minimização. de custos (despesa de juros), a função de bem-estar (função-objeti vo) abrange amplamente as metas politicas desejadas. Contudo, cer- 
tos objetivos somente podem ser estabelecidos em termos de restriçōes.

Uma queda, em qualquer período do plano, do consumo "per cap $\underline{i}$ ta", mesmo que conduza a uma melhora substancial no consumo futuro, é decididamente um evento indesejável. Pelo contrário, espera-se que o consumo "per capita" tenha, pelo menos, um crescimento minimo estipulado a cada ano. Tal objetivo é incluido no modelo através de uma restrição que requeira um crescimento do consumo total a uma taxa que represente a evolução minima desejada do consumo "per capita":

$$
C_{t} \geq(1+p)\left(1+c_{I}\right) C_{t-1} .
$$

Um pais, normalmente, necessita manter :eservas internacionais para prevenir quaisquer eventualidades que dificultem ou im possibilitem o cumprimento de obrigaçōes de curto prazo no seu relacionamento econömico com o exterior. E costume fazer com que tais reservas sejam suficientes para cobrir as despesas de importação de um determinado número de meses. Assim, seria uma boa medida estabelecer-se um limite mínimo para a variāvel em tela, em função das importaçōes. Por outro lado, não seria desejāvel manter as reservas internacionais em niveis muito elevados, pelo fato de serem as despesas de sua manutenção (taxa de juros internacionais mais "spread") maiores do que as receitas de sua aplicação (apenas taxa de juros internacionais). Dessa maneira, seria também plausivel apor-se um limite máximo para as reservas internacionais tão próximo possivel do limite mínimo. Por isso, ao invés de duas restricooes (uma superior e outra inferior), preferiu-se manter as reservas internacionais em um nivel não mais do que suficiente para fazer face às eventualidades citadas. Isto é, formalmente, optou-se por estabelecer uma igualdade entre tal variável e uma fração das importaçōes, sendo que a estas soma-se a despesa liquida de juros ${ }^{3}$

(3) A rigor, deveria ser somada às importações a despesa de juros, eis que a re ceita pertence às exportaçōes. Por não se terem desmembradas a despesa e $\bar{a}$ receita de juros, preferiu-se utilizar, para efeito da equação (2.19), a des pesa líquida de juros (despesa menos receita). 
e abate-se a parcela da produção para melhoramento da balança comercial $^{4}$ que se supōe ser destinada à substituição de importaçōes:

$$
R_{t}=f\left(M_{t}+J_{t}-e p_{t}^{m}\right) \text {. }
$$

Não é propriamente o valor absoluto da divida externa que importa, mas os custos dela provenientes (comparativamente com os be neficiss obtidos) e a capacidade de pagamento dos compromissos assumidos. Os custos estão diretamente relacionados com as taxas de ju ros internacionais e o "spread" praticados e a capacidade de paga mento da fonte de divisas, que são as exportaçōes. Assim, três são os aspectos mais relevantes do endividamento externo: o preço (taxa de juros mais "spread"), o prazo e o nível de exportaçōes. Os dois primeiros dependem, em parte, das condiçōes do mercado internacional e, em parte, das negociaçōes a cada operação realizada, enquanto o $\bar{u}^{\dagger}$ timo constitui-se em uma limitação para o volume global de empréstimos e, em consequēncia, da dívida externa. No presente modelo, procura-se manter uma relação máxima - representada pelo parāmetro c - entre a dívida externa líquida e as exportaçōes, sendo que a estas acrescenta-se a parcela da produção para melhora mento da balança comercial dedicada à expansão das exportaçōes:

$$
D_{t} \equiv c\left[X_{t}+(i-e) P_{t}^{m}\right]+R_{t}
$$

Tem sido um desejo da sociedade tornar-se independente, em ter mos económicos, dos recursos externos, em virtude dos pesados encargos decorrentes das excessivas elevaçōes das taxas de juros internacionais e dos altissimos "spreads" praticados. Um dos objetivos básicos do presente trabalho é justamente estudar-se a possibi lidade de se reverter a trajetōria da divida externa, bem como as consequēncias de tal reversão. Por isso, colocou-se uma restrição em que, a partir de determinado ano, não mais se tomam empréstimos:

$$
\begin{aligned}
& \mathrm{E}_{\mathrm{t}} \stackrel{e}{=}, \\
& \text { para } \mathrm{t}=\mathrm{T}-\mathrm{n}, \ldots, \mathrm{T} .
\end{aligned}
$$

(4) Não está definida no modelo a distribuição quantitativa da produção para me1 horamento da balança comercial entre substituição de importaçōes e expansão de exportaçōes. Entretanto, apenas para efeito das equações (2.19) e $(2.20)=$ atribuiu-se uma fraçāo (e) para substituiçào de importaçōes e o res tante $(1-e)$ para expansão de exportaçōes. 
Na teoria dos dois hiatos ${ }^{5}$, a evolução da divida é função da taxa planejada de crescimento do produto. Tal evolução passa por trēs estágios, sendo que o último é aquele em que não mais há necessidade de poupança externa, pois a poupança doméstica é suficiente para fazer-se o investimento requerido pelo crescimento pla nejado e para pagarem-se os juros e a amortização da dívida. Com a restrição (2.22), pretende-se permutar a causa com a consequência (como são apresentadas pela teoria), isto é, procura-se saber qual seria a taxa de crescimento do produto ao longo do período do plano, no caso de se forçar a entrada do serviço da dívida no terceiro estágio. Note-se que o ponto de transiçāo entre o segundo e o terceiro estágios do serviço da dívida poderá nāo ser o ano em que não mais se tomarāo empréstimos, tendo em vista que, antes disto, as amortizaçōes poderão ser superiores aos empréstimos, causando o declínio da divida externa bruta.

\section{OS DADOS}

A aplicação do modelo exposto no capítulo anterior requer valo res da maioria das variáveis (relativos ao ano-base e à amortização programada para todos os anos abrangidos pelo planol e dos parāmetros estruturais e nāo-estruturais.

Os valores das variáveis do ano-base e das relativas à amorti zaçāo programada - cujos índices variam de 0 a 20 , correspondendo respectivamente aos anos de 1981 a 2001 - estāo relacionados na Ta bela 3.1 .

(5) Veja-se Motta (1982), pảg. 28 e seguintes. 
Tabela 3.1

VALORES DAS VARIAVEIS DE ENTRADA DO MODELO

Cr\$ milhōes

\begin{tabular}{|c|c|c|c|c|c|c|}
\hline Var. & & Valor & Var. & Valor & Var. & Valor \\
\hline$c_{0}$ & & 379719,2 & $\mathrm{~A}_{2}^{\mathrm{P}}$ & 635526,0 & $\mathrm{~A}_{12}^{\mathrm{p}}$ & 30095,1 \\
\hline $\mathrm{D}_{0}$ & & 704222,1 & $\mathrm{~A}_{3}^{\mathrm{p}}$ & 637476,6 & $\mathrm{~A}_{13}^{\mathrm{p}}$ & 24150,4 \\
\hline $\mathrm{I}_{0}$ & 5 & 151055,7 & $\mathrm{~A}_{4}^{\mathrm{P}}$ & $678 \quad 810,9$ & $\mathrm{~A}_{14}^{\mathrm{P}}$ & 16812,4 \\
\hline$I_{0}^{d}$ & & 145738,1 & $\mathrm{~A}_{5}^{\mathrm{P}}$ & 721352,7 & $\mathrm{~A}_{15}^{\mathrm{p}}$ & 13189,8 \\
\hline $\mathrm{M}_{0}$ & 2 & 457983,6 & $A_{6}^{p}$ & 682805,0 & $\mathrm{~A}_{16}^{\mathrm{p}}$ & 11517,9 \\
\hline $\mathrm{P}_{0}$ & 25 & 424131,1 & $\mathrm{~A}_{7}^{\mathrm{P}}$ & 652059,7 & $\mathrm{~A}_{17}^{\mathrm{p}}$ & 9474,4 \\
\hline $\mathrm{R}_{0}$ & & 697295,2 & $\mathrm{~A}_{8}^{\mathrm{p}}$ & 427832,9 & $\mathrm{~A}_{18}^{\mathrm{P}}$ & 8174,0 \\
\hline$s_{0}$ & & 044419,9 & $\mathrm{~A}_{9}^{\mathrm{p}}$ & 195339,3 & $\mathrm{~A}_{19}^{\mathrm{p}}$ & 6409,1 \\
\hline$x_{0}$ & & 203850,4 & $\mathrm{~A}_{10}^{\mathrm{P}}$ & 127532,5 & $\mathrm{~A}_{20}^{\mathrm{p}}$ & 5944,7 \\
\hline $\mathrm{A}_{1}^{\mathrm{p}}$ & & 669150,7 & $\mathrm{~A}_{1 ;}^{\mathrm{p}}$ & 42356,0 & & \\
\hline
\end{tabular}

Fontes: Banco Central do Brasil, revista Conjuntura de março de 1982 e cálculos do autor.

Os valores dos parâmetros estruturais estão contidos na Tabela 3.2. Embora os cálculos estejam melhor explicados em Motta (1982), listam-se abaixo como alguns deles foram obtidos:

a) a (dois valores para formação de alternativas: o primeiro c om base em dados do periodo 1970-77, e o segundo, 1970-31):

$$
\begin{aligned}
S_{t}=3149,642+0,185 P_{t} & \left(R^{2}=0,9487\right) \\
(0,0176) & (D . W .=2,9819) ; 0 u \\
s_{t}=18390,954+0,131 P_{t} & \left(R^{2}=0,8555\right) \\
(0,0170) & (D . w .=1,0965) ;
\end{aligned}
$$


b) $m^{c} \in m^{i}$ :

$$
\begin{aligned}
M_{t}=-10750,9774+ & 0,0165 C_{t}+0,5086 I_{t}\left(R^{2}=0,8668\right) \\
(0,0578) \quad(0,2421) \quad(D . w . & =1,3873) ;
\end{aligned}
$$

c) $\mathrm{x}$ :

$$
\begin{aligned}
\log x_{t}=4,11925+0,03914 t & \left(\mathrm{R}^{2}=0,9148\right) \\
(0,0038) & (\mathrm{D} \cdot \mathrm{w} .=1,3006) ;
\end{aligned}
$$

$$
\begin{aligned}
\log (1+x) & =0,03914 ; \\
x & =\operatorname{antilog}(0,03914)-1 ; \\
x & =0,0943 ;
\end{aligned}
$$

d) $\mathrm{k}^{\mathrm{c}}$ :

$$
\begin{aligned}
& k^{c}=\frac{t=1970 I_{t}}{P_{1981-P_{1970}}} \\
& k^{c}=\frac{737304,3}{466123,5-208275,9} \approx 2,9 .
\end{aligned}
$$

Tabela 3.2

VALORES DOS PARANATTROS ESTRUTURAIS UTILIZADOS NO MODELO

\begin{tabular}{c|l|c|c}
\hline Parâmetro & \multicolumn{1}{|c|}{ Valor } & Parāmetro & Valor \\
\hline$\alpha$ & 0,185 ou 0,113 & $\mathrm{ml}^{\mathrm{c}}$ & 0,0165 \\
$\beta$ & 0,166 & $\mathrm{~m}^{\mathrm{i}}$ & 0,5086 \\
$k^{\mathrm{c}}$ & 2,9 & $\mathrm{p}$ & 0,0248 \\
$k^{\mathrm{m}}$ & 4,5 & $\mathrm{x}$ & 0,0943 \\
\hline
\end{tabular}

FONTES: p - resultado do ültimo censo; demais - cálculos do autor. 
o processo utilizado para o cálculo de $k^{c}$ foi baseado no de Heesterman (1972, pág. 104). Para $k^{\mathrm{m}}$, tento em vista a dificuldade de cálculo, optou-se por atribuir-se o valor de 4,5, igual ao de Chenery-ikacEwan (1966), uma vez que o valor calculado de $k^{c}(2,9)$ para o caso brasileiro se assemelha aos utilizados naquele artigo $(2,9$ e 3,0$)$.

O valor atribuido a $k(0,166)$ corresponde ao maior valor encon trado no período 1970-1981.

Os valores dos parâmetros nāo-estruturais encontram-se na Tabela 3.3 .

Tabela 3.3

VALORES DOS PARAMETROS NAO-ESTRUTURAIS

UTILIZADOS NO MODELO

\begin{tabular}{c|c|c|c}
\hline Parāme tros & \multicolumn{1}{|c|}{ valor } & varãmetros & valor \\
\hline n & 2,544 ou 2,7126 & $\mathrm{i}$ & 0,08 \\
0,05 & $\mathrm{j}^{\mathrm{i}}$ & 0,09 \\
$\mathrm{a}$ & 8 & $\mathrm{j}^{\mathrm{s}}$ & 0,0213 \\
$\mathrm{c}$ & $\mathrm{m}$ & $\mathrm{m}$ & 3 \\
$\mathrm{~d}$ & 0,1 & $\mathrm{q}$ & 0,015 \\
$\mathrm{e}$ & 0,5 & $\mathrm{r}$ & 0,1 \\
$\mathrm{f}$ & 0,25 & $\mathrm{~T}$ & 20 \\
\hline
\end{tabular}

FONTE: cálculos e escolihas do autor.

Os valores de alguns parâmetros nāo-estruturais foram escolh dos pelo autor com base numa possivel convergência de opiniōes a respeito dos desejos da sociedade brasileira. Os de outros - como a e $\mathrm{m}$, por exemplo - foram atribuídos tendo em vista observaçōes ao compor tamento das autoridades econômicas brasileiras no relacio narento do Pais com o exterior. Outros ainda foram calculados a par it des valuxes de outros parâmetros, como segue: 
a) $\rho$ (foi escolhido livremente, embora a taxa marginal de pou pança da 1 a hipótese $(0,185)$ permita-se chegar ao valor es colhido) :

$$
\rho=\frac{\alpha}{\frac{k^{c}+k^{m}}{2}}=\frac{0,185}{\frac{2,9+4,5}{2}}=0,05 \text {; }
$$

b) $n$ :

$$
\begin{aligned}
& n=\left(1-\alpha_{t}\right) \quad \sum_{t=1}^{\infty} \frac{(1+p)^{t}}{(1+r)^{T+t^{2}}} ; \\
& n=\frac{\left(1-\alpha_{t}\right)}{(1+r)^{T}} \quad . \quad \sum_{t=1}^{\infty}\left(\frac{1+\rho}{1+r}\right)^{t} ; \\
& \eta=\frac{\left(1-\alpha_{t}\right)}{(1+r)^{T}} \quad \cdot \quad \frac{\frac{1+\rho}{1+r}}{1-\frac{1+\rho}{1+r}} \\
& n=\frac{\left(1-\alpha_{t}\right)}{(1+r)^{T}} \quad \cdot \quad \frac{1+\rho}{r-\rho} \\
& n=\frac{1-0,185}{(1+0,1)^{20}} \quad \cdot \quad \frac{1+0,5}{0,1-0,05} \\
& \eta \cong 2,44 ; \text { ou } \\
& n=\left(1-\alpha_{T}\right) \quad \sum_{t=1}^{\infty} \frac{(1+\rho)^{t}}{(1+r)^{T+t}} \approx 2,7126 .
\end{aligned}
$$

Serão apresentadas, no presente artigo, apenas quatro alterna tivas $^{1}$.

A primeira delas - a solução básica - denomina-se Al, enquanto a segunda recebe a denominação de Al-S. Ambas contēm a restrição ("2.22), que força a não-utilização de empréstimos no último ano do plano. A diferença entre elas reside nas taxas marginal de poupança utilizada: enquanto na primeira é de $18,5 \%$, na segunda é de $13,1 \%$.

(1) Veja-se MOTrA (1982), onde sã apresentadas 10 alternativas. 
o outro conjunto A5 e A5-S, que tem a mesma distinção quanto à taxa marginal de poupança, caracteriza-se pela não-inclusão da restrição (2.22), ou seja, os empréstimos continuariam a ser tomados livremente.

\section{4 - OS RE SULTADOS}

As ciuatro alternativas devem ser comparadas duas a duas: Al contra AS e Al-S contra A5-S. Isto porque as alternativas Al e Al-S, tendo em vista a restrição (2.22), que obriga que os empréstimos do último ano do plano (2001) sejam nulos, retratam o desejo de um inicio de pagamento da divida externa, ao passo que as alternativas A5 e A5-S representam planos em que a preocupação maior é o crescimento do produto, mantendo-se a dívida externa limitada apenas pelo nivel de exportações ${ }^{1}$.

As Tabelas $4.1,4.2$ e 4.3 expõem os resultados da alternativa Al, respectivamente, em bilhões de cruzeiros, em bilhões de dólares, ambos a precos de 1981, e em taxas anuais de crescimento. As Tabelas 4.4, 4.5 e 4.6 apresentam os resultados da alternativas A1-S, A5 e A5-S, respectivamente, apenas em bilhões de dölares, a preços de 1981 .

Todas as listagens de computador ${ }^{2}$ contendo os resultados das quatro alternativas encontram-se em poder do autor. Em especial, pa ra a alternativa Al foi impressa uma seçāo denominada "Picture", que consiste de uma representação da matriz do modelo, contendo 402 linhas, 722 variáveis (as quais incluem uma variável de folga para cada linha), 2528 elementos e uma densidade 0,87099:.

Os comentários serāo dirigidos apenas a duas variāveis: $\mathrm{P}$ (pro duto nacional bruto) e D(divida externa).

(1) Vejam-se as restrições (2.21) e (2.22).

(2) O sistema computacional utilizado foi o B7700/B6700 Systems - Tempo - Mathe matical Programuing System, da Burroughs Corporation. 
Tabela 4.1

ALternativa A1: RESULtAdDOS EM Cr\$ BILHOES, A PRECOS DE 1981

Cr $\$$ BILHOES

\begin{tabular}{|c|c|c|c|c|c|c|c|c|c|c|c|c|c|c|c|c|}
\hline $\begin{array}{l}\text { VARIAVEL } \\
\text { ANO }\end{array}$ & A & C & D & $E$ & I &.$I^{C}$ & $I^{D}$ & $I^{M}$ & $J$ & $M$ & $P$ & $p^{C}$ & $\mathrm{p}^{\mathrm{M}}$ & R & $s$ & $x$ \\
\hline 1981 & 716 & 21380 & 5704 & 1658 & 5151 & 5151 & 146 & 0 & 853 & 2458 & 25424 & 25424 & 0 & 697 & 4044 & 2204 \\
\hline 1982 & 669 & 22278 & 7222 & 2187 & 5461 & 5151 & 160 & 310 & 572 & 3257 & 26321 & 26321 & 0 & 957 & 4043 & 2412 \\
\hline 1983 & 636 & 23173 & 8358 & 1772 & 5461 & 5151 & 176 & 310 & 718 & 3272 & 27352 & 27283 & 69 & 989 & 4179 & 2639 \\
\hline 1984 & 1002 & 24105 & 9294. & 1937 & 5461 & 5151 & 194 & 310 & 841 & 3287 & 28462 & 28325 & 138 & 1015 & 4357 & 2888 \\
\hline 1985 & 1339 & 25443 & 10101 & 2145 & 5636 & 5327 & 213 & 310 & 943 & 3399 & 30104 & 29897 & 206 & 1060 & 4661 & 3160 \\
\hline 1986 & 1704 & 28485 & 11230 & 2834 & 6572 & 6263 & 235 & 310 & 1029 & 3925 & 33837 & 33562 & 275 & 1204 & 5352 & 3458 \\
\hline 1987 & 2023 & 30956 & 12394 & 3187 & 7222 & 6913 & 258 & 310 & 1142 & 4296 & 36868 & 36525 & 344 & 1317 & 5913 & 3784 \\
\hline 1988 & 2465 & 32954 & 13605 & 3676 & 7746 & 7436 & 284 & 310 & 1261 & 4672 & 39321 & 39908 & 413 & 1432 & 6366 & 4141 \\
\hline 1989 & 2772 & 35100 & 14932 & 4099 & 8355 & 8046 & 312 & 310 & 1385 & 5130 & 41953 & 41472 & 481 & 1569 & 6853 & 4532 \\
\hline 1990 & 2788 & 37417 & 16374 & 4230 & 9016 & 8706 & 344 & 310 & 1521 & 5625 & 44796 & 44246 & 550 & 1718 & 7379 & 4959 \\
\hline 1991 & 3108 & 39920 & 17942 & 4676 & 9731 & 9422 & 378 & 310 & 1668 & 6162 & 47867 & 47248 & 619 & 1880 & 7947 & 5427 \\
\hline 1992 & 3405 & 42623 & 19110 & 4574 & 10076 & 9766 & 416 & 310 & 1828 & 6314 & 51184 & 50497 & 688 & 1949 & 8561 & 5939 \\
\hline 1993 & 3815 & 45424 & 21612 & 6317 & 11749 & 11439 & 457 & 310 & 1952 & 7855 & 54621 & 53864 & 757 & 2357 & 9197 & 6499 \\
\hline 1994 & 4099 & . 48695 & 23015 & 5501 & 11845 & 11535 & 503 & 310 & 2193 & 7649 & 58634 & 57808 & 825 & 2357 & 9939 & 7111 \\
\hline 1995 & 4613 & 51992 & 23608 & 5206 & 11845 & 11535 & 553 & 310 & 2349 & 7484 & 62680 & 61786 & 894 & 2347 & 10688 & 7782 \\
\hline 1996 & 4914 & 55290 & 23413 & 4718 & 11845 & 11535 & 609 & 310 & 2416 & 7471 & 66726 & 65763 & 963 & 2351 & 11436 & 8516 \\
\hline 1997 & 5096 & 58587 & 22426 & 4109 & 11845 & 11535 & 670 & 310 & 2394 & 7616 & 70772 & 69740 & 1032 & 2374 & 12185 & 9319 \\
\hline 1998 & 5176 & 61885 & 20642 & 3392 & 11845 & 11535 & 737 & 310 & 2282 & 7927 & 74818 & 73718 & 1100 & 2415 & 12933 & 10198 \\
\hline 1999 & 5080 & 65183 & 18056 & 2495 & 11845 & 11535 & 810 & 310 & 2080 & 8411 & 78864 & 77695 & 1169 & 2477 & 13682 & 11159 \\
\hline 2000 & 4881 & 67803 & 14856 & 1681 & 11845 & 11535 & 891 & 310 & 1787 & 9231 & 82080 & 80842 & 1238 & 2600 & 14277 & 12212 \\
\hline 2001 & 4244 & 71778 & 10612 & 0 & 11845 & 11535 & 980 & 310 & 1420 & 9916 & 86957 & 86650 & 1307 & 2671 & 15179 & 13363 \\
\hline
\end{tabular}

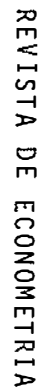


US\$ BILHŐES

A)

\begin{tabular}{|c|c|c|c|c|c|c|c|c|c|c|c|c|c|c|c|c|}
\hline VARIAVEL & A & $c$ & D & E & I & $I^{C}$ & $\mathrm{I}^{\mathrm{D}}$ & $I^{M}$ & J & $M$ & $\mathrm{p}$ & $\mathrm{p}^{\mathrm{C}}$ & $\mathrm{p}^{M}$ & $\mathrm{R}$ & $\mathrm{s}$ & $\mathrm{x}$ \\
\hline 1981 & 7.7 & 30.2 & 61.4 & 17.8 & 55.5 & 55.5 & 1.6 & .0 & 9.2 & 26.5 & 273.7 & 273.7 & .0 & 7.5 & 43.5 & 23.7 \\
\hline 1982 & 7.2 & 239.8 & 77.8 & 23.5 & 58.8 & 55.5 & 1.7 & 3.3 & 6.2 & 35.1 & 283.4 & 283.4 & .0 & 10.3 & 43.5 & 26.0 \\
\hline 1983 & 6.8 & 249.5 & 90.0 & 19.1 & 58.8 & 55.5 & 1.9 & 3.3 & 7.7 & $: 5.2$ & 294.5 & 293.7 & .7 & 10.6 & 45.0 & 28.4 \\
\hline 1984 & 10.8 & 259.5 & 100.1 & 20.9 & 58.8 & 55.5 & 2.1 & 3.3 & 9.1 & 35.4 & 306.4 & 304.9 & 1.5 & 10.9 & 46.9 & 31.1 \\
\hline 1985 & 14.4 & 273.9 & 108.7 & 23.1 & 60.7 & 57.3 & 2.3 & 3.3 & 10.2 & 36.6 & 324.1 & 321.9 & 2.2 & 11.4 & 50.2 & 34.0 \\
\hline 1986 & 18.3 & 306.7 & 120.9 & 30.5 & 70.8 & 67.4 & 2.5 & 3.3 & 11.1 & 42.3 & 364.3 & 361.3 & 3.0 & 13.0 & 57.6 & 37.2 \\
\hline 1987 & 21.8 & 333.3 & 133.4 & 34.3 & 77.8 & 74.4 & 2.8 & 3.3 & 12.3 & 46.3 & 396.9 & 393.2 & 3.7 & 14.2 & 63.7 & 40.7 \\
\hline 1988 & 26.5 & 354.8 & 146.5 & 39.6 & 83.4 & 80.1 & 3.1 & 3.3 & 13.6 & 50.3 & 423.3 & 418.9 & 4.4 & 15.4 & 68.5 & 44.6 \\
\hline 1989 & 29.8 & 377.9 & 160.8 & 44.1 & 89.9 & 86.6 & 3.4 & 3.3 & 14.9 & 55.2 & 451.7 & 446.5 & 5.2 & 16.9 & 73.8 & 48.8 \\
\hline 1990 & 30.0 & 402.8 & 176.3 & 45.5 & 97.1 & 93.7 & 3.7 & 3.3 & 16.4 & 60.6 & 482.3 & 476.3 & 5.9 & 18.5 & 79.4 & 53.4 \\
\hline 1991 & 33.5 & 429.8 & 193.2 & 50.3 & 104.8 & 101.4 & 4.1 & 3.3 & 18.0 & 66.3 & 515.3 & 508.7 & 6.7 & 20.2 & 85.6 & 58.4 \\
\hline 1992 & 36.7 & 458.9 & 205.7 & 49.2 & 108.5 & 105.1 & 4.5 & 3.3 & 19.7 & 68.0 & 551.0 & 543.6 & 7.4 & 21.0 & 92.2 & 63.9 \\
\hline 1993 & 41.1 & 489.0 & 232.7 & 68.0 & 126.5 & 123.2 & 4.9 & 3.3 & 21.0 & 84.6 & 588.0 & 579.9 & 8.1 & 25.4 & 99.0 & 70.0 \\
\hline 1994 & 44.1 & 524.2 & 247.8 & 59.2 & 127.5 & 124.2 & 5.4 & 3.3 & 23.6 & 82.3 & 631.2 & 622.4 & 8.9 & 25.4 & 107.0 & 76.6 \\
\hline 1995 & 49.7 & 559.7 & 254.2 & 56.0 & 127.5 & 124.2 & 6.0 & 3.3 & 25.3 & 80.6 & 674.8 & 665.2 & 9.6 & 25.3 & 115.1 & 83.8 \\
\hline 1996 & 52.9 & 595.2 & 252.1 & 50.8 & 127.5 & 124.2 & 6.6 & 3.3 & 26.0 & 80.4 & 718.4 & 708.0 & 10.4 & 25.3 & 123.1 & 91.7 \\
\hline 1997 & 54.9 & 630.7 & 241.4 & 44.2 & 127.5 & 124.2 & 7.2 & 3.3 & 25.8 & 82.0 & 761.9 & 750.8 & 11.1 & 25.6 & 131.2 & 100.3 \\
\hline 1998 & 55.7 & 666.2 & 222.2 & 36.5 & 127.5 & 124.2 & 7.9 & 3.3 & 24.6 & 85.3 & 805.5 & 793.6 & 11.8 & 26.0 & 139.2 & 109.8 \\
\hline 1999 & 54.7 & 701.8 & 194.4 & 26.9 & 127.5 & 124.2 & 8.7 & 3.3 & 22.4 & 90.6 & 849.0 & 836.5 & 12.6 & 26.7 & 147.3 & 120.1 \\
\hline 2000 & 52.5 & 730.0 & 159.9 & 18.1 & 127.5 & 124.2 & 9.6 & 3.3 & 19.2 & 99.4 & 883.7 & 870.3 & 13.3 & 28.0 & 153.7 & 131.5 \\
\hline 2001 & 45.7 & 772.8 & 114.2 & .0 & 127.5 & 124.2 & 10.6 & 3.3 & 15.3 & 106.8 & 936.2 & 922.1 & 14.1 & 28.8 & 163.4 & 143.9 \\
\hline
\end{tabular}




\begin{tabular}{|c|c|c|c|c|c|c|c|c|c|c|c|c|c|c|c|c|}
\hline VARIAVEL & A & C & D & E & I & $I^{C}$ & $I^{D}$ & $I^{M}$ & J & M & $\mathrm{P}$ & $\mathrm{p}^{\mathrm{C}}$ & $\mathrm{p}^{\mathrm{M}}$ & $\mathbf{R}$ & S & $x$ \\
\hline . & $-6,6$ & 4,2 & 26,6 & 31,9 & 6,0 & , 0 & 9,6 & - & $-32,9$ & 32,5 & 3,5 & 3,5 &, 0 & 37,3 & 0 & 9,4 \\
\hline 1983 & $-4,9$ & 4,0 & 15,7 & $-19,0$ & 0 &, 0 & 10,0 & 0 & 25,5 &, 5 & 3,9 & 3,7 & .0 & 3,3 & 3,4 & 9,4 \\
\hline 1984 & 57,5 & 4,0 & 11,2 & 9,3 & , 0 & 0 & 10,2 &, 0 & 17,1 &, 5 & 4,1 & 3,8 & - & 2,6 & 4,3 & 9,4 \\
\hline 1985 & 33,6 & 5,6 & 8,7 & 10,7 & 3,2 & 3,4 & 9,8 &, 0 & 12,1 & 3,4 & 5,8 & 5,5 & 49,3 & 4,4 & 7,0 & 9,4 \\
\hline 1986 & 27,3 & 12,0 & 11,2 & 32,1 & 16,6 & 17,6 & 10,3 &, 0 & 9,1 & 15,5 & 12,4 & 12,3 & 33,5 & 13,6 & 14,8 & 9,4 \\
\hline 1987 & 18,7 & 8,7 & 10,4 & 12,5 & 9,9 & 10,4 & 9,8 &, 0 & 11,0 & 9,5 & 9,0 & 8,8 & 25,1 & 9,4 & 10,5 & 9,4 \\
\hline 1988 & 21,8 & 6,5 & 9,8 & 15,3 & 7,3 & 7,6 & 10,1 & , 0 & 10,4 & 8,8 & 6,7 & 6,5 & 20,1 & 8,7 & 7,7 & 9,4 \\
\hline 1989 & 12,5 & 6,5 & 9,8 & 11,5 & 7,9 & 8,2 & 9,9 & 0 & 9,8 & 9,8 & 6,7 & 6,6 & 16,5 & 9,6 & 7,7 & 9,4 \\
\hline 1990 & , 6 & 6,6 & 9,7 & 3,2 & 7,9 & 8,2 & 10,3 &, 0 & 9,8 & 9,6 & 6,8 & 6,7 & 14,3 & 9,5 & 7,7 & 9,4 \\
\hline 1991 & 11,5 & 6,7 & 9,6 & 10,5 & 7,9 & 8,2 & 9,9 &, 0 & 9,7 & 9,5 & 6,9 & 6,8 & 12,5 & 9,4 & 7,7 & 9,4 \\
\hline 1992 & 9,6 & 6,8 & 6,5 & $-2,2$ & 3,5 & 3,7 & 10,1 &, 0 & 9,6 & 2,5 & 6,9 & 6,9 & 11,1 & 3,7 & 7,7 & 9,4 \\
\hline 1993 & $-12,0$ & 6,6 & 13,1 & 38,1 & 16,6 & 17,1 & 9,9 &, 0 & 6,8 & 24,4 & 6,7 & 6,7 & 10,0 & 20,9 & 7,4 & 9,4 \\
\hline 1994 & 7,4 & 7,2 & 6,5 & $-12,9$ &, 8 & , 8 & 10,1 &, 0 & 12,3 & $-2,6$ & 7,3 & 7,3 & 9,0 & ,0 & 8,1 & 9,4 \\
\hline 1995 & 12,5 & 6,8 & 2,6 & $-5,4$ &, 0 &, 0 & 9,9 &, 0 & 7,1 & $-2,2$ & 6,9 & 6,9 & 8,4 &,- 4 & 7,5 & 9,4 \\
\hline 1996 & 6,5 & 6,3 &,- 8 & $-9,4$ & 0 & , 0 & 10,1 &, 0 & 2,9 &,- 2 & 6,5 & 6,4 & 7,7 & , 2 & 7,0 & 9,4 \\
\hline 1997 & 3,7 & 6,0 & $-4,2$ & $-12,9$ & 0 &, 0 & 10,0 &, 0 &,- 9 & 1,9 & 6,1 & 6,0 & 7,2 & 1,0 & 6,5 & 9,4 \\
\hline 1998 & 1,6 & 5,6 & $-8,0$ & $-17,4$ &, 0 &, 0 & 10,0 &, 0 & $-4,7$ & 4,1 & 5,7 & 5,7 & 6,6 & 1,7 & 6,1 & 9,4 \\
\hline 1999 & $-1,9$ & 5,3 & $-12,5$ & $-26,4$ & 0 &, 0 & 9,9 &, 0 & $-8,9$ & 6,1 & 5,4 & 5,4 & 6,3 & 2,6 & 5,8 & 9,4 \\
\hline 2000 & $-3,9$ & 4,0 & $-17,7$ & $-32,6$ &, 0 & 0 & 10,0 & , 0 & $-14,1$ & 9,7 & 4,1 & 4,1 & 5,9 & 5,0 & 4,3 & 9,4 \\
\hline 2001 & $-13,1$ & 5,9 & $-28,6$ & $-100,0$ &, 0 & 0 & 10,0 &, 0 & $-20,5$ & 7,4 & 5,9 & 5,9 & 5,6 & 2,7 & 6,3 & 9,4 \\
\hline
\end{tabular}


Tabela 4.4

ALtERnATIVA A1-S: RESULTADOS EN US\$ BILHOES, A PRECOS DE 198:

Al $-\$$

US\$ BILHÕES

尚

\begin{tabular}{|c|c|c|c|c|c|c|c|c|c|c|c|c|c|c|c|c|}
\hline VARISVEL & A & C & D & E & I & $I^{C}$ & $\mathrm{I}^{\mathrm{D}}$ & $I^{M}$ & $\mathrm{~J}$ & $M$ & $P$ & $P^{C}$ & $\mathrm{p}^{\mathrm{N}}$ & $\mathbf{R}$ & $\mathrm{S}$ & $x$ \\
\hline 1981 & 7.7 & 230.2 & 61.4 & 17.8 & 55.5 & 55.5 & 1.6 & .0 & 9.2 & 26.5 & 273.7 & 273.7 & .0 & 7.5 & 43.5 & 23.7 \\
\hline 1982 & 7.2 & 239.8 & 77.7 & 23.5 & 58.7 & 55.5 & 1.7 & 3.2 & 6.2 & 35.0 & 283.3 & 283.3 & .0 & 10.3 & 43.5 & 26.0 \\
\hline 1983 & 6.8 & 24.9 .5 & 89.9 & 19.0 & 58.7 & 55.5 & 1.9 & 3.2 & 7.7 & 35.2 & 294.4 & 293.7 & .7 & 10.6 & 44.9 & 28.4 \\
\hline 1984 & 10.8 & 261.9 & 100.0 & 20.9 & 58.7 & 55.5 & 2.1 & 3.2 & 9.0 & 35.4 & 308.6 & 307.2 & 1.4 & 10.9 & 46.8 & 31.1 \\
\hline 1985 & 14.4 & 287.2 & 109,9 & 24.3 & 62.1 & 58.9 & 2.3 & 3.2 & 10.1 & 37.5 & 337.8 & 335.7 & 2.2 & 11.6 & 50.6 & 34.0 \\
\hline 1986 & 18.3 & 318.1 & 121.1 & 29.5 & 67.8 & 64.6 & 2.5 & 3.2 & 11.2 & 41.4 & 373.5 & 370.5 & 2.9 & 12.8 & 55.3 & 37.2 \\
\hline 1987 & 22.0 & 338.1 & 133.2 & 34.1 & 71.9 & 68.7 & 2.8 & 3.2 & 12.3 & 45.6 & 396.4 & 392.8 & 3.6 & 14.0 & 58.3 & 40.7 \\
\hline 1988 & 26.6 & 359.3 & 146.3 & 39.7 & 76.3 & 73.1 & 3.1 & 3.2 & 13.6 & 50.2 & 420.8 & 416.4 & 4.3 & 15.4 & 61.5 & 44.6 \\
\hline 1989 & 29.8 & 381.8 & 160.5 & 44.1 & 81.0 & 77.8 & 3.4 & 3.2 & 14.9 & 55.1 & 446.7 & 441.6 & 5.0 & 16.9 & 64.9 & 48.8 \\
\hline 1990 & 30.0 & 405.7 & 170.0 & 45.5 & 86.1 & 82.8 & 3.7 & 3.2 & 16.3 & 60.4 & 474.2 & 468.4 & 5.7 & 18.5 & 68.5 & 53.4 \\
\hline 1991 & 33.5 & 431.2 & 189.0 & 46.5 & 88.4 & 85.2 & 4.1 & 3.2 & 17.9 & 63.1 & 503.5 & 497.0 & 6.5 & 19.4 & 72.3 & 58.4 \\
\hline 1992 & 36.6 & 457.3 & 197.2 & 44.8 & 88.4 & 85.2 & 4.5 & 3.2 & 19.3 & 64.0 & 533.6 & 526.4 & 7.2 & 19.9 & 76.3 & 63.9 \\
\hline 1993 & 40.2 & 483.5 & 201.2 & 44.1 & 88.4 & 85.2 & 4.9 & 3.2 & 20.2 & 66.0 & 563.7 & 555.8 & 7.9 & 20.5 & 80.2 & 70.0 \\
\hline 1994 & 42.7 & 509.6 & 200.8 & 42.3 & 88.4 & 85.2 & 5.4 & 3.2 & 20.5 & 68.9 & 593.8 & 585.1 & 8.6 & 21.3 & 84.1 & 76.6 \\
\hline 1995 & 44.3 & 535.8 & 196.1 & 39.6 & 88.4 & 85.2 & 6.0 & 3.2 & 20.4 & 73.0 & 623.9 & 614.5 & 9.3 & 22.2 & 88.1 & 83.8 \\
\hline 1996 & 44.7 & 561.9 & 187.0 & 35.7 & 88.4 & 85.2 & 6.6 & 3.2 & 19.8 & 78.3 & 654.0 & 643.9 & 10.1 & 23.3 & 92.0 & 91.7 \\
\hline 1997 & 44.0 & 588.1 & 173.6 & 30.5 & 88.4 & 85.2 & 7.2 & 3.2 & 18.7 & 84.9 & 684.1 & 673.3 & 10.8 & 24.5 & 96.0 & 100.3 \\
\hline 1998 & 42.3 & 614.2 & 155.6 & 24.4 & 88.4 & 85.2 & 7.9 & 3.2 & 17.1 & 92.7 & 714.2 & 702.7 & 11.5 & 26.0 & 99.9 & 109.8 \\
\hline 1999 & 39.6 & 640.2 & 133.2 & 17.2 & 88.4 & 85.2 & 8.7 & 3.2 & 15.0 & 101.8 & 744.0 & 732.0 & 12.0 & 27.7 & 103.8 & 120.1 \\
\hline 2000 & 36.2 & 665.9 & 106.3 & 9.3 & 88.4 & 85.2 & 9.6 & 3.2 & 12.3 & 112.8 & 773.6 & 760.7 & 12.9 & 29.7 & 107.7 & 131.5 \\
\hline 2001 & 31.7 & 692.7 & 74.6 & .0 & 88.4 & 85.2 & 10.6 & 3.2 & 9.2 & 125.1 & 804.4 & 790.8 & 13.7 & 31.8 & 111.7 & 143.9 \\
\hline
\end{tabular}


Tabela 4.5

As

\begin{tabular}{|c|c|c|c|c|c|c|c|c|c|c|c|c|c|c|c|c|}
\hline VARIĀVEL & $A$ & C & D & $\mathrm{E}$ & I & $\mathrm{I}^{\mathrm{C}}$ & $I^{D}$ & $I^{M}$ & $\mathrm{~J}$ & $M$ & $P$ & $P^{C}$ & $\mathrm{P}^{\mathrm{M}}$ & $R$ & $\mathrm{~s}$ & $x$ \\
\hline 1981 & 7.7 & 230.2 & 61.4 & 17.8 & 55.5 & 55.5 & 1.6 & .0 & 9.2 & 26.5 & 273.7 & 273.7 & .0 & 7.5 & 43.5 & 23.7 \\
\hline 1982 & 7.2 & 239.8 & 77.8 & 23.5 & 58.8 & 55.5 & 1.7 & 3.3 & 6.2 & 35.1 & 283.4 & 283.4 & .0 & 10.3 & 43.5 & 26.0 \\
\hline 1983 & 6.8 & 249.5 & 90.0 & 19.1 & 58.8 & 55.5 & 1.9 & 3.3 & 7.7 & 35.2 & 294.5 & 293.7 & .7 & 10.6 & 45.0 & 28.4 \\
\hline 1984 & 10.8 & 259.5 & 100.1 & 20.9 & 58.8 & 55.5 & 2.1 & 3.3 & 9.1 & 35.4 & 306.4 & 304.9 & 1.5 & 10.9 & 46.9 & 31.1 \\
\hline 1985 & 14.4 & 275.1 & 109.1 & 23.5 & 61.3 & 57.4 & 2.3 & 3.9 & 10.2 & 36.9 & 325.6 & 323.4 & 2.2 & 11.5 & 50.5 & 34.0 \\
\hline 1986 & 18.3 & 308.4 & 121.6 & 30.8 & 71.5 & 67.6 & 2.5 & 3.9 & 11.1 & 42.6 & 366.4 & 363.3 & 3.1 & 13.0 & 58.0 & 37.2 \\
\hline 1987 & 21.9 & 333.5 & 133.7 & 34.0 & 77.5 & 73.6 & 2.8 & 3.9 & 12.4 & 46.1 & 397.2 & 393.3 & 3.9 & 14.1 & 63.7 & 40.7 \\
\hline 1988 & 26.7 & 354.9 & 147.1 & 40.0 & 83.6 & 79.7 & 3.1 & 3.9 & 13.6 & 50.8 & 423.5 & 418.7 & 4.8 & 15.5 & 68.6 & 44.6 \\
\hline 1989 & 29.9 & 378.0 & 161.5 & 44.4 & 90.2 & 86.3 & 3.4 & 3.9 & 15.0 & 55.8 & 451.8 & 446.2 & 5.7 & 17.0 & 73.8 & 48.8 \\
\hline 1990 & 30.1 & 403.0 & 177.2 & 45.9 & 97.3 & 93.4 & 3.7 & 3.9 & 16.5 & 61.3 & 482.4 & 475.9 & 6.5 & 18.6 & 79.5 & 53.4 \\
\hline 1991 & 33.6 & 429.9 & 194.3 & 50.7 & 105.0 & 101.1 & 4.1 & 3.9 & 18.1 & 67.1 & 515.5 & 508.1 & 7.4 & 20.4 & 85.6 & 58.4 \\
\hline 1992 & 36.9 & 459.0 & 212.9 & 55.4 & 113.3 & 109.4 & 4.5 & 3.9 & 19.8 & 73.5 & 551.2 & 543.0 & 8.3 & 22.3 & 92.2 & 63.9 \\
\hline 1993 & 41.3 & 490.5 & 233.0 & 61.5 & 122.4 & 118.5 & 4.9 & 3.9 & 21.7 & 80.4 & 589.8 & 580.7 & 9.1 & 24.4 & 99.3 & 70.0 \\
\hline 1994 & 45.3 & 524.5 & 255.0 & 67.3 & 132.2 & 128.3 & 5.4 & 3.9 & 23.7 & 87.9 & 631.5 & 621.5 & 10.0 & 26.7 & 107.1 & 76.6 \\
\hline 1995 & 49.8 & 561.2 & 278.9 & 73.7 & 142.8 & 138.9 & 6.0 & 3.9 & 26.0 & 96.0 & 676.6 & 665.8 & 10.8 & 29.1 & 115.4 & 83.8 \\
\hline 1996 & 54.3 & 601.0 & 304.9 & 80.4 & 154.3 & 150.4 & 6.6 & 3.9 & 28.4 & 104.8 & 725.4 & 713.7 & 11.7 & 31.9 & 124.4 & 91.7 \\
\hline 1997 & 59.2 & 643.9 & 333.3 & 87.6 & 166.8 & 162.9 & 7.2 & 3.9 & 31.1 & 114.4 & 778.1 & 765.5 & 12.6 & 34.8 & 134.2 & 100.3 \\
\hline 1998 & 65.0 & 690.9 & 364.2 & 95.9 & 180.4 & 176.5 & 7.9 & 3.9 & 34.0 & 124.9 & 835.1 & 821.7 & 13.4 & 38.0 & 144.7 & 109.8 \\
\hline 1999 & 71.1 & 740.7 & 398.0 & 104.8 & 195.1 & 191.2 & 8.7 & 3.9 & 37.1 & 136.2 & 896.8 & 882.6 & 14.3 & 41.6 & 156.1 & 120.1 \\
\hline 2000 & 77.8 & 795.1 & 434.7 & 114.6 & 211.0 & 207.1 & 9.6 & 3.9 & 40.6 & 148.6 & 963.6 & 948.5 & 15.2 & 45.4 & 168.5 & 131.5 \\
\hline 2001 & 85.0 & 871.4 & 474.8 & 125.1 & 211.0 & 207.1 & 10.6 & 3.9 & 44.3 & 162.1 & 1035.9 & 1019.9 & 16.0 & 49.6 & 164.5 & 143.9 \\
\hline
\end{tabular}

US\$ BILHסES

0
$⿱$
0
0
0
0
0
0
$m$
0
0
0
0
0
3
$m$
0
0
0
0 
Tabela 4.6

ALTERNATIVA A5-S: RESLLTADOS EM US\$ BILHOES, A PRECOS DE 1981

$A B-S$

US\$ BILHOES

\begin{tabular}{|c|c|c|c|c|c|c|c|c|c|c|c|c|c|c|c|c|}
\hline VAR & A & c & D & $\mathrm{E}$ & I & $I^{C}$ & $I^{D}$ & $I^{M}$ & J & $M$ & $\mathrm{P}$ & $\mathrm{p}^{\mathrm{C}}$ & $\mathrm{p}^{M}$ & $\mathrm{R}$ & $\mathrm{s}$ & $\mathrm{x}$ \\
\hline 1981 & 7.7 & 230.2 & 61.4 & 17.8 & 55.5 & 55.5 & 1.6 & .0 & 9.2 & 26.5 & 273.7 & 273.7 & .0 & 7.5 & 43.5 & 23.7 \\
\hline 1982 & 7.2 & 239.8 & 77.7 & 23.5 & 58.7 & 55.5 & 1.7 & 3.2 & 6.2 & 35.0 & 283.3 & 283.3 & .0 & 10.3 & 43.5 & 26.0 \\
\hline 1983 & 6.8 & 249.5 & 89.9 & 19.0 & 58.7 & 55.5 & 1.9 & 3.2 & 7.7 & 35.2 & 2916.4 & 293.7 & .7 & 10.6 & 44.9 & 28.4 \\
\hline 1984 & 10.8 & 261.9 & 100.0 & 20.9 & 58.7 & 55.5 & 2.1 & 3.2 & 9.0 & 35.4 & 308.6 & 307.2 & 1.4 & 10.9 & 46.8 & 31.1 \\
\hline 1985 & 14.4 & 287.2 & 109.9 & 24.3 & 62.1 & 58.9 & 2.3 & 3.2 & 10.1 & 37.5 & 337.8 & 335.7 & 2.2 & 11.6 & 50.6 & 34.0 \\
\hline 1986 & 18.3 & 318.1 & 121.1 & 29.5 & 67.8 & 64.6 & 2.5 & 3.2 & 11.2 & 41.4 & 373.4 & 370.5 & 2.9 & 12.8 & 55.3 & 37.2 \\
\hline 1987 & 22.0 & 338.1 & 133.2 & 34.1 & 71.9 & 68.7 & 2.8 & 3.2 & 12.3 & 45.6 & 396.4 & 392.8 & 3.6 & 14.0 & 58.3 & 40.7 \\
\hline 1988 & 26.6 & 359.3 & 146.3 & 39.7 & 76.3 & 73.1 & 3.1 & 3.2 & 13.6 & 50.2 & 420.8 & 416.4 & 4.3 & 15.4 & 61.5 & 44.6 \\
\hline 1989 & 29.8 & 381.8 & 160.5 & 44.1 & 81.0 & 77.8 & 3.4 & 3.2 & 14.9 & 55.1 & 446.7 & 441.6 & 5.0 & 16.9 & 64.9 & 48.8 \\
\hline 1990 & 30.0 & 405.7 & 176.0 & 45.5 & 86.1 & 82.8 & 3.7 & 3.2 & 16.3 & 60.4 & 474.2 & 468.4 & 5.7 & 18.5 & 68.5 & 53.4 \\
\hline 1991 & 33.5 & 431.2 & 192.8 & 50.3 & 91.5 & 88.2 & 4.1 & 3.2 & 17.9 & 66.1 & 503.5 & 497.0 & 6.5 & 20.2 & 72.3 & 58.4 \\
\hline 1992 & 36.6 & 458.2 & 211.2 & 55.0 & 97.3 & 94.1 & 4.5 & 3.2 & 19.6 & 72.4 & 534.6 & 527.4 & 7.2 & 22.1 & 76.4 & 63.9 \\
\hline 1993 & 40.8 & 487.0 & 231.1 & 60.8 & 103.5 & 100.3 & 4.9 & 3.2 & 21.5 & 79.2 & 567.8 & 559.9 & 7.9 & 24.2 & 80.7 & 70.0 \\
\hline 1994 & 45.0 & 517.7 & 252.9 & 66.8 & 110.3 & 107.0 & 5.4 & 3.2 & 23.5 & 86.5 & 603.1 & 594.5 & 8.6 & 26.4 & 85.4 & 76.6 \\
\hline 1995 & 49.4 & 550.4 & 276.6 & 73.1 & 117.5 & $11 / . .2$ & 6.0 & 3.2 & 25.8 & 94.5 & 640.7 & 631.4 & 9.3 & 28.9 & 90.3 & 83.8 \\
\hline 1996 & 53.9 & 585.3 & 302.4 & 79.7 & 125.2 & 122.0 & 6.6 & 3.2 & 28.2 & 103.2 & 680.8 & 670.7 & 10.1 & 31.6 & 95.5 & 91.7 \\
\hline 1997 & 58.7 & 622.4 & 330.5 & 86.9 & 133.6 & 130.3 & 7.2 & 3.2 & 30.8 & 112.7 & 723.6 & 712.8 & 10.8 & 34.5 & 101.1 & 100.3 \\
\hline 1998 & 64.4 & 662.1 & 361.2 & 95.1 & 142.6 & 139.3 & 7.9 & 3.2 & 33.7 & 123.0 & 769.2 & 757.7 & 11.5 & 37.7 & 107.1 & 109.8 \\
\hline 1999 & 70.5 & 704.5 & 394.7 & 104.0 & 152.2 & 149.0 & 8.7 & 3.2 & 36.8 & 134.3 & 818.0 & 805.8 & 12.2 & 41.2 & 113.5 & 120.1 \\
\hline 2000 & 77.1 & 749.8 & 431.3 & 113.7 & 162.7 & 159.4 & 9.6 & 3.2 & 40.2 & 146.5 & 870.1 & 857.2 & 12.9 & 45.1 & 120.3 & 131.5 \\
\hline 2001 & 84.3 & 809.4 & 471.2 & 124.2 & 162.7 & 159.4 & 10.6 & 3.2 & 43.9 & 159.9 & 925.8 & 912.1 & 13.7 & 49.2 & !16.4 & 143.9 \\
\hline
\end{tabular}


Com os dados pertinentes à variável $\mathrm{P}$ das 4 alternativas escolhidas - dados encontrados nas tabelas deste cápítulo -, elaborou-se o Gráfico 4.1. Este gráfico permite a comparação do comportamento, entre as alternativas em questão, apenas do produto. Tal comparação mostra claramente que a alternativa que conduz a re sultados mais favoráveis, principalmente no que tange a valores fi nais, em termos de níveis de produto, é a A5 (Cr\$ 96221 bilhōes em 2001), seguida de Al (Cr\$86 957 bilhöes), da A5-S (Cr\$ 85993 bilhöes) e da Al-S (Cr\$74 722 bilhöes).

O Gráfico 4.2 apresenta, da mesma forma como foi feito para o produto, a evolução apenas da dívida externa (variável D). Neste caso, evidentemente, a alternativa mais favorável em termos de resultado final é a Al-S, pois chegar-se-ia a 2001 com uma dívida ex terna de Cr\$6932 bilhōes (aumento de 21,58 em relação a 1981). As alternativas seguintes são a Al, com o valor final de Cr\$ 10612 bilhōes (aumento de 86\%), a A5-S, com o de Cr\$43 766 bilhōes (aumento de 667,28 ) e a A5, como o de Cr\$44 106 bilhöes (aumento de $673,2 \%$ ).

Veja-se agora o Gráfico 4.3. Comparando-se a alternativa Al com a A5 (para ambas a taxa marginal de poupança é igual a $18,5 \%$ ), nota-se que a evolução do produto é mais ou menos semelhante até 1995 e que somente a partir desse ano, tendo em vista a continuida de do crescimento de ingresso de recursos externos, o produto, na alternativa A5, começa a crescer mais rapidamente do que na alternativa Al. Quanto à dívida externa, a evolução é semelhante para ambas as alternativas até 1993, ano a partir do qual, na alternati va Al, começa a haver desaceleração da trajetōria. Nesta alternatí va, a dívida externa atinge o pico em 1995 (Cr\$ 23608 bilhōes), passando a cair rapidamente, enquanto, na alternativa $A 5$, o cresci mento da dívida externa continua a uma taxa anual em torno de 9,4\%, permitida pela taxa de crescimento das exportaçōes (9,4\% a.a), através da restrição $(2.21)$.

O Gráfico 4.4 permite a comparação entre as alternativas Al-S e A5-S. Os produtos dos anos até 1991 inclusive são exatamente iguais nas duas alternativas. Somente a partir de 1992 passa a ocorrer maior aceleração do crescimento do produto na alternativa A5-S. Os valores da dívida externa também são iguais até 1990 in- 
(P)

BILHOES

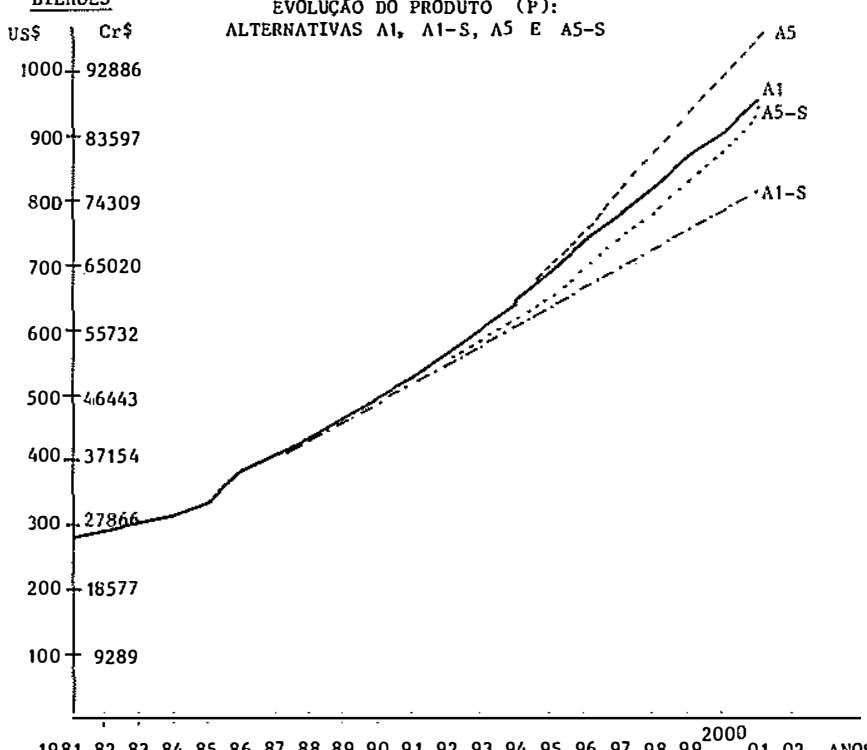

Gräfico 4.

EVOLUÇAO DO PRODUTO ( $\mathrm{P}$ ):

TERNATIVAS $\Lambda 1, \Lambda 1-S, \Lambda S$ E AS-S
(D)

BILI10ES US\$ Cr\$ $500-46443$

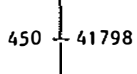

$400--37154$

$350-32510$

$300-27866$

250

$200+18577$

$150 \stackrel{13933}{ }$

$100+9289$

50 
$(P \perp D)$

MLLHOES

uS\$ Cr\$

$1000+92886$

$900-83597$

$800+74309$

$700-65020$

$600+55732$

$500+46443$

$400-37154$

30

$200-18577$

100

100

Grätico 4.3

PRODUTO (P) $\times$ DIVIDI EXTERNA (D): ALTERNATEVAS AIE AS

$\Lambda 5(\mathrm{P})$

$\wedge 1(\mathrm{P})$

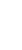

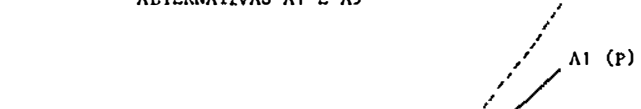

$\begin{array}{llllllllllllllllllll}1981 & 82 & 83 & 84 & 85 & 86 & 87 & 88 & 89 & 90 & 91 & 92 & 93 & 94 & 95 & 96 & 97 & 98 & 99^{2000} 0102 & \text { NNOS }\end{array}$

$$
\text { (P e D) }
$$

BILHOES

Grafico 4.4

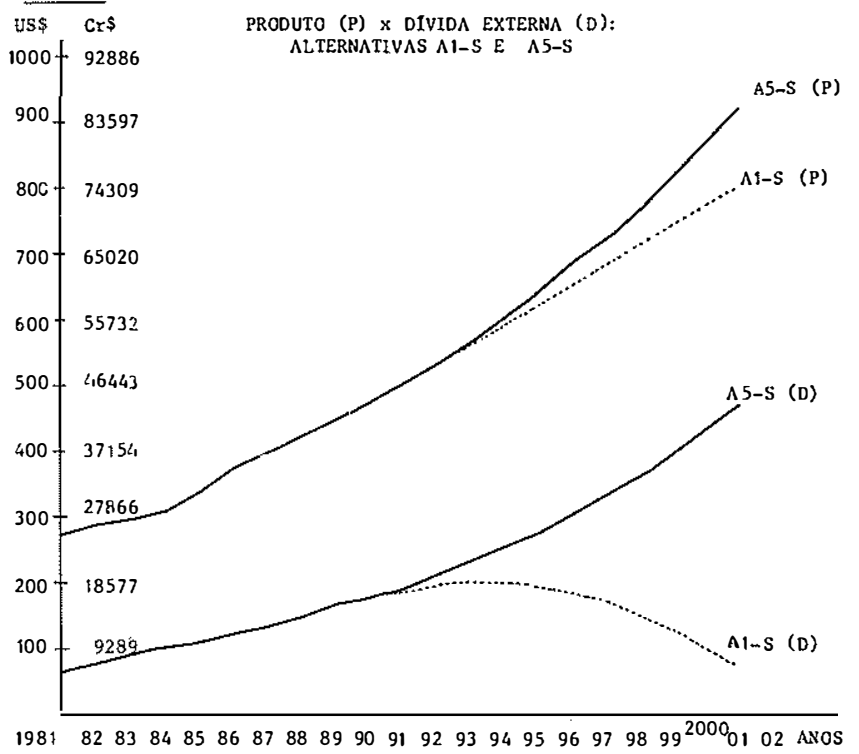


clusive, ano a partir do qual passa a haver desaceleração do seu crescimento na alternativa Al-S. Nesta alternativa, tem-se como pí co para a divida externa o valor de Cr\$18 685 bilhōes em 1993, ano em que a divida começa a declinar até o final do plano, ao passo que na A5-S a evolução da variável em questão tem a mesma carac teristica da alternativa A5, qual seja, taxa de crescimento em tor no de 9.4: a.a., limitada apenas pela restrição (2.21).

Reúnem-se, na Tabela 4.7, alguns parâmetros que possibilitam melhor análise comparativa das alternativas escolhidas. Na referida tabela, encontram-se: na primeira coluna, os códigos das alternativas; na segunda, o crescimento percentual do produto do ano 2001 em relação ao do ano de 1981; na terceira, o crescimento percentual da dívida externa de 2001 em relação à de 1981; na quarta, a relação entre o crescimento percentual do produto (segunda coluna) e o da dívida externa (terceira coluna); na quinta, a relação percentual divida externa/produto do ano 2001 (tais valores podem ser comparados com o valor da mesma relação referente ao ano de 1981, qual seja, 22,48); e nas duas ültimas, as taxas percentuais anuais médias de crescimento do produto e da divida externa, respectivamente.

Tabela 4.7

PARAMETRDS PARA COMPARAÇÃO, ENTRE AS ALTERNATIVAS AT, A5, AI-S E A5-S, DA EVOLUÇAOO DO PRODUTO E DA DIVIDA EXTERNA.

\begin{tabular}{|c|c|c|c|c|c|c|}
\hline \multirow{2}{*}{ ALTERNATIVA } & \multicolumn{2}{|c|}{$\begin{array}{l}\text { CRE SCIMENTO PERCEN- } \\
\text { TUAL }(\%)-2001 / 1981 \\
\end{array}$} & \multirow{2}{*}{$\% \mathrm{P} / \% \mathrm{D}$} & \multirow{2}{*}{$\begin{array}{l}\text { RELACAO PERCEN } \\
\text { TUAL DIVIDA EX } \\
\text { TERNA/PRODUTO } \\
\text { (2001) }\end{array}$} & \multicolumn{2}{|c|}{$\begin{array}{l}\text { TAXA PERCENTUAL MEDIA } \\
\text { DE CRESCIMENTO ANUAL }\end{array}$} \\
\hline & PRODUTO & $\begin{array}{r}\text { DIVIDA } \\
\text { EXTERNA }\end{array}$ & & & PRODUTO & $\begin{array}{r}\text { DIVIDA } \\
\text { EXTERNA }\end{array}$ \\
\hline $\mathrm{Al}$ & 242,0 & 86,0 & 2,81 & 12,2 & 6,4 & 4,0 \\
\hline AS & 278,5 & 673,2 & 0,41 & 45,8 & 6,9 & 10,8 \\
\hline Al-S & 193,9 & 21,5 & 9,02 & 9,3 & 5,6 & 1,9 \\
\hline A S-S & 238,2 & 667,3 & 0,36 & 50,9 & 6,3 & 10,8 \\
\hline
\end{tabular}

FONTE: cälculos do autor. 
A comparação da alternativa Al (ou Al-S) - que inclui esforço no sentido de pagar-se efetivamente a divida externa, consubstanciado na aposição da restrição obrigando ser nulo o nivel de empréstimos do ũltimo ano do plano - com a A5 (ou A5-S) - que apenas objetiva máximo crescimento do produto, sem maiores preocupações com a evolução da divida externa -, através dos números apresentados pela tabelas e dos gráficos deste capítulo, já é suficiente para sugerir promoção de politica no sentido de tornar a economia brasileira independente dos recursos externos. os parâmetros contidos na Tabela 4.7 vêm ratificar tal sugestão. Em primeiro lugar, um rápido exame das segunda e terceira colunas da referida tabela permite verificar que o ganho de crescimento do pro duto tanto da alternativa Al para a AS como da Al-S para a A5-S é mais do que compensado pela perda representada pelo crescimento da divida externa $(242,0 \%$ para $278,5 \%$ contra $86 \%$ para $673,2 \%$; e 193,98 para 238,28 contra 21,58 para 667,38). A quarta coluna mostra a ques tão ainda mais claramente: a relaçāo percentual do produto/percentual da divida externa ( $8 \mathrm{P} / \not D)$ quandoé igual ã unidade significa que o crescimento das duas variáveis, em termos relativos, é idêntico; quando é maior do que a unidade, o crescimento relativo do produto é superior ao da dívida externa; e vice-versa, quando é menor do que 1. Na alternativa Al, o parâmetro em tela assume o valor de 2,81, que é o número devezes em que o crescimento do produto supera o da divida externa; na alternativa Al-S o produto cresce 9,02 vezes mais do que a dívida externa. Por outro lado, o produto tem um cres cimento, nos casos das alternativas A5 e A5-S, igual a 0,41 e 0,36, respectivamente, do crescimento da dívida externa. Por isso que, conforme se pode constatar pela leitura da última coluna, a relação percentual divida externa/produto, que em 1981 era de 22,4 , cai, no ano 2001, nos casos das alternativas $A l(12,2 \%)$ e Al-S $(9,3 \%)$ e eleva-se nos casos das alternativas A5 $(45,8 \%)$ e A5-S $(50,98)$.

As duas últimas colunas também servem para a comparaçāo entre as alternativas Al (ou Al-S) e a A5 (ou A5-S). No primeiro caso, a uma grande elevação da taxa média de crescimento anual da divida externa - 6,8 pontos percentuais, correspondendo ã elevação de 4,0z a.a. da alternativa Al para 10,88 a.a. da A5 - corresponde um pequeno ganho em termos de pruduto - apenas 0,5 ponto percentual, derivado do acréscimo de $6,4 \%$..a. da alternativa Al para 6,9\% a.a da 
A5. A mesma comparação feita entre as alternativas Al-S e A5-S mo tra que o excessivo aumento da taxa média anual de crescimento da dívida externa de 8,9 pontos percentuais 11,98 a.a. da primeira pa ra 10,88 da segunda) produz um relativamente baixo crescimento da taxa correspondente ao produto, qual seja, 0,7 ponto percentual (5,6 a.a. da primeira para 6,32 a.a. da segunda).

'Lorna-se, então, evidente que tanto os percentuais elevados da divida externa em relação ao produto do ano terminal do plano quanto os pequenos ganhos de crescimento médio anual do produto comparativamente aos da divida externa não aconselham definitivamente a utilização de políticas de desenvolvimento calcadas em poupança externa, mas sim aquelas voltadas ao pagamento da dívida externa e que conduzam a crescimentos auto-sustentados do produto, ainda que a taxas mais modestas.

Outro fato que se observa através do exame da Tabela 4.7 é a importância de se implementarem medidas no sentido de melhorar a poupança doméstica, em contraposição a maior endividamento externo. Comparando-se a alternativa Al - que contém restrição que anula o nivel de empréstimos do ano terminal do plano e taxa marginal de poupança igual a 18,5: - com a A5-S - sem aquela restrição e com taxa marginal de poupança igual a $13,18-$, nota-se que o produto do ano terminal da primeira cresce mais do que o da segunda $(242,0 z$ contra $238,2 \%$ ), com uma relação divida externa/produto, também do ano terminal, da primeira bastante inferior ao da segunda $(12,28$ contra 50,9\%). Este é realmente um dado impressionante, pois uma melhoria da taxa marginal de poupança de $13,1 \%$ para 18,5\% produz me lhor resultado em termos de crescimento do produto do que chegar-se a 2001 com uma relação divida externa/produto 4,2 (50,9z/12,2z) vezes maior.

A observação do parágrafo anterior pode ser corroborada pela comparação entre as alternativas Al e A5-S, no que concerne às taxas médias de crescimento anual do produto e da divida externa. A Tabela 4.7 mostra perfeitamente que uma melhora na taxa marginal de poupança é superior a um maior endividamente na busca de maiores taxas médias de crescimento do produto. Para que esta afirmação possa ser comprovada, suponha-se que a economia tenha escolhido a alternativa Al-3, onde possui uma taxa marginal de poupança 
de 13,1\% e se implementará politica de pagamento efetivo da divida externa. Este segundo objetivo será satisfeito, pois, como se pode observar na referida tabela, a taxa média de crescimento anual da dívida externa será de apenas 1,98 a.a., e a taxa média de crescimento do produto será de 5,6: a.a. Suponha-se ainda que se deseje aumentar esta última taxa. Para tal, os tomadores de decisão se vēem diante de duas alternativas: aumentar o endividamento externo (passar para a alternativa A5-S); ou melhorar a taxa margi nal de poupança (alternativa Al). Com um maior endividamento, alcançar-se-ia o objetivo, eis que a taxa média de crescimento do pro duto seria elevada de $5,6 \%$ a.a. para $6,3 \%$ a.a., mas às custas de uma enorme elevação da taxa média de crescimento anual da dívida externa que passaria de 1,98 a.a. para 10,8\% a.a. Por outro lado, com uma politica que pudesse elevar a taxa marginal de poupança de 13,18 para $18,5 \%$, alcançar-se-ia um melhor resultado em termos de taxa média de crescimento do produto, que atingiria 6,4\% a.a. com uma elevaçāo da taxa média de crescimento da divida para apenas $4,0 \%$, bastante inferior à da outra hipótese.

Assim sendo, outra conclusāo importante a que se chega é que, dentro do contexto apresentado pelo modelo, uma politica no sentido de melhorar de forma razoável a taxa marginal de poupança, além dos efeitos óbvios em termos de crescimento da divida externa, pode produzir maiores crescimentos do produto do que uma política de intenso endividamento externo.

Quanto à viabilidade de se implementar um plano que torne a economia brasileira independente dos recursos externos, isto é, que possibilite iniciar-se o pagamento efetivo da divida externa, os resultados das alternativas Al e Al-S fornecem algumas respostas. As evoluçōes do produto e da divida externa nas alternativas citadas atestam que nāo só tais pretensōes são viāveis como não há necessidade de grandes sacrificios ${ }^{3}$ para torná-las realidade. Entretanto, a realização de tais desígnios exige que duas condiçōes sejam satisfeitas. A primeira refere-se à continuidade do endividamento, ou seja, há necessidade de que os banqueiros internacionais

(3) Note-se que, nas alternativas citadas, o crescimento do zonsumo em nenhum ano é inferior a $4 \%$, r ssultado da preocupaça inicial que motivou a aposição da restrição politicica (2.19). 
continuem ainda dispostos a conceder ao Brasil volumes crescentes de empréstimos por um período que varia de 10 a 15 anos. A segunda refere-se à melhoria da capacidade de pagamento, através de melhoramento da balança comercial. Urge reunir esforços no sentido de promover-se, no que for possível, substituiçāo de bens e serviços importados por produtos nacionais idēnticos ou sucedāneos. Esforço maior deve ser canalizado para o setor exportador, no sentido de aumentar-se ainda mais, nos próximos anos, a taxa de crescimento anual das exportaçōes, que, na década de 70, já não foi baixa lem torno de $9,4:$ a.a.).

\section{5 - CONCL USÖES}

Os resultados das quatro alternativas mostram que é possivel escolher tanto um caminho de altas taxas de crescimento do produto com uma grande expansão da dívida externa (alternativas A5 e A5-S) quanto outra de taxas de crescimento do produto mais modestas, que permita conter dentro de certos limites a evoluçāo da dívida exter na (alternativas Al e Al-S).

Entretanto, as opções que conduzem a maiores endividamentos, implicando também abrir mão de taxas de crescimento do produtomais altas, derrem ser postas fora de cogitação por diversos motivos. Um deles refere-se à velocidade de crescimento da dívida externa comparada com o a do produto. Outro motivo relaciona-se com a argumen taçāo de que a importação de capital tem influēncia negativa sobre a poupança interna e a relação incremental capital/produto e, por conseguinte, não promove a aceleração do crescimento do produto. Um outro motivo - e este é decisivo - refere-se ao fato de que a época de disponibilidade de recursos e de crédito fácil no mercado financeiro internacional parece ter chegado ao fim. Dessa forma, tem -se que levar em conta a contenção da dívida externa em qualquer plano de desenvolvimento.

Pelo que foi exposto no parágrafo anterior, as alternativas do modelo factíveis e desejáveis seriam aquelas que contēm a restrição (2.22), que obriga não se tomaren empréstimos no ano terminal do plano, quais sejam, alternativas Al e Al-s. 
Até mesmo no caso das alternativas Al e Al-s há necessidade de que a divida continue a crescer ainda por mais algum tempo. Na al ternativa Al-S, a dívida externa cresce até 1993, quando atinge o pico de todo o período. A luz, então, desses resultados, chega-se à conclusāode que a dívida externa precisa continuar aumentandopor um periodo entre 12 e 14 anos, a contar do ano-base de 1981, para passar à fase em que ela poderá começar a ser efetivamente saldada. E bem verdade que o modelo apresentado neste trabalho abrange uina restrição política que não permite crescimentos do consumo "per capita" inferiores a $1,5 \%$ a.a.". Talvez fosse o caso, devido à futura provável crescente escassez de recursos no mercado financeiro internacional, de retirar-se tal alternativa e de encurtar-se o pe ríodo de crescimento da dívida externa através de antecipação do ano a partir do qual os empréstimos se tornariam nulos ${ }^{2}$. Mas, apesar de que medidas desse porte viessem a possibilitar teoricamente uma antecjpação do início do pagamento efetivo da dívida externa, o conseqtente baixo crescimento do produto, além da possibilidade de causar graves problemas sociais, poderia, na prática, inviabilizar tal desejo, eis que altas taxas de crescimento do produto e do investimento constituem-se em uma das pré-condiçōes de manutençāo a longo prazo de capacidade de pagar amortizaçōes. Assim, de qualquer modo, é preciso que os banqueiros internacionais continuem dis postos a não só financiar o "rolamento" da dívida externa mas também a carrear algum recurso líquido, a fim de que o País mantenha, ainda por mais alguns anos, sua estratégia de ajustar-se à nova rea lidade internacional de altos preços de energia e de divisas.

Finalmente, caso certas condiçōes - tais como a disposição dos banqueiros internacionais em financiar o serviço da dívida e o investimento necessário ao ajustamento econômico à nova realidade in ternacional - não possam ser satisfeitas, urge tomarem-se interna e independentemente decisōes que possam supri-las, ainda que elas afetem o relacionamento econômico do País com o exterior.

(1) Vejammse restrições (2.19) e o valor de q na tabela 3.3.

(2) Seria o caso ampliar-se para mais anos a restriçào (2.22). Nas alternativas Al e Al-S, a restriçào é aplicada apenas para o ültimo ano do plano. 


\section{REFERENCIAS}

BRASIL (värios anos). Banco Central do Brasil, Boletim Mensal, di versos números.

BRASIL (1980). República Federativa do Brasil, III Plano Nacional de Desenvolvimento - III PND. (1980/85).

BURROUGHS Corporation (1976). B 7700/B6700 Systems Tempo, Mathemat cal Programing Sustem, User's Manual, Detroit.

CHENERY. H.B e MACEWAN, A. (1966). Optimal Pateterns of Growth and Aid: The Case of Pakistan. The Theory and Design of Economic Development, editado por Irma Adelman e Erik Thorbecke, The Johns Hopkins Press, Baltimore, pägs. 149-80.

CHIANG, A.C. (1967). Fundamental Methods of Mathematical Economics, McGraw - Hill Book Company, New York.

DANTZIG, G.B. (1963). Linear Programming and Extensions, Princeton University Press, Princeton, N.J.

DORFMAN, R., SAMUELSON, P.A. e SOLOW, R.M. (1958). Linear Programming and Economic Analysis, McGraw - Hill Book Company, New York.

FUNDAÇAo getúlio VARGAS (vários anos). Revista Conjuntura, mar ço, de 1982 e outros números.

HADLEY, G. (1975). Linear Programing, 9th print., Addison-Wesley Publishing Company Inc., Reading, Massachusetts.

HEALEY, J.M. (1971). The Economic of Aid, Toutledge S. Keegan, Lon don.

HeEsterman, A. (1972). Forecasting Models for National Economic Planning, D. Riedel Publishing Company.

INTRILLIGATOR, M.D. (1977). Mathematical Optimization and Eccnomic Theory, Prentice - Hall Inc., Englewoods Cliffs, N.J.

MOTTA, R.S. (1982). Alternativas de Otimização do Crescimento Econōmico e da Dívida Externa: O Caso do Brasil. Escola de Adminis tração Fazendária, Centro de Pesquisa, Brasilia (DF).

SHIBly, M. e ThIRLWALl, A.P. (1981). Dual-Gap Analysis for the Sudan, World Developement, Vol. 9, Pergamon Press Ltd., Great Britain, pägs. 193-200.

TINBERGEN, J. (1970). A Didactical Note on the Two-Gap Theory, Induction, Growth and Trade (Essays in Honour of Sir Roy Harrod), ed. por W.A. Eltis, M.Fg. Scott e J.N. Wolfe, Clarendon Press, oxford. 